\title{
The Comparative Evaluation of the Time to Peak Concentration and the Terminal Half-Life of Two Products Based on Praziquantel in a Bioequivalence Study
}

\author{
Alexandra ARION ${ }^{1}$, István TÖRÖK ${ }^{2}$, Ferenc NAGY², Annamária IMRE ${ }^{2}$, Francisc Andrei BODA², Cristina \\ ŞTEFĂNUȚ ${ }^{1}$, Ildiko BARABASI ${ }^{1}$, Laurenț OGNEAN ${ }^{1 *}$ \\ ${ }^{1}$ University of Agricultural Sciences and Veterinary Medicine, Faculty of Veterinary Medicine, Cluj- \\ Napoca \\ ${ }^{2}$ VIM Spectrum, Tg. Mureş \\ Corresponding author: lognean@yahoo.com
}

Bulletin UASVM Veterinary Medicine 72(1) / 2015,

Print ISSN 1843-5270; Electronic ISSN 1843-5378

DOI:10.15835/buasvmcn-vm: 10668

\begin{abstract}
$\mathrm{T}_{\max }$ represents the amount of time necessary to achieve the maximum concentration of the drug in the systemic circulation. The half time of a drug represents the mandatory time required to reduce the drugs concentration from the plasma to half, after reaching a steady state.

Evaluating and comparing the time to attain the maximum drug concentration in the blood $\left(\mathrm{T}_{\max }\right)$ and to assess the half-time $\left(\mathrm{T}_{1 / 2}\right)$ of praziquantel in two drug formulations, in a bioequivalence study. These measurements were carried out with regard to the peak concentration $\left(\mathrm{C}_{\max }\right)$ of the drugs. In the study, were included 12 healthy cats, of European breed. According to the study protocol, the cats received praziquantel, in a dosage of $20 \mathrm{mg}$, in two phases, at different time periods, for three consecutive days. A series of parameters were determined, including $\mathrm{T}_{\max }, \mathrm{T}_{1 / 2}$, and $\mathrm{C}_{\text {max }}$. It was observed that, at the same amount of praziquantel $(20 \mathrm{mg})$, the results were different. For the first group, the maximum substance concentration was at $1.18 \pm 0.4$ hours and for the second group, was at $1.27 \pm 0.26$ hours. The half-time was at $1.07 \pm 0.22$ hours for the first group while for the second group was at $1.84 \pm 1.16$ hours. The results of the investigated parameters revealed mainly individual differences, which were situated within the bioequivalence standards.
\end{abstract}

Keywords: bioequivalence, praziquantel, $T_{1 / 2}, T_{\max }$

\section{INTRODUCTION}

Bioequivalence tests are a way to evaluate the efficacy of a drug. In the bioequivalence study a number of closely related parameters are evaluated (Ognean et al., 2008). Among these parameters are the time to peak concentration (Tmax), representing the necessary time needed for the active substance to reach the maximum concentration in blood or the necessary time needed for the active substance to reach it's halflife $\left(\mathrm{T}_{1 / 2}\right)$. These parameters are determined according to the maximum absorbed substance in the body (Cristina and Chirciu, 2010).

\section{AIM AND OBJECTIVES}

The study aims to evaluate and compare the necessary time to attain the maximum drug concentration in the blood $\left(\mathrm{T}_{\max }\right)$ and to assess the half-time $\left(\mathrm{T}_{1 / 2}\right)$ of praziquantel in two drug formulations, in a bioequivalence study.

\section{MATERIAL AND METHODS}

In the study, 12 cats of European breed were included, clinically healthy, coming from rural or urban environment. The cats were admitted for testing according to a series of inclusion/exclusion criteria. Each subject was submitted to an initial screening, consisting of clinical, hematological and 


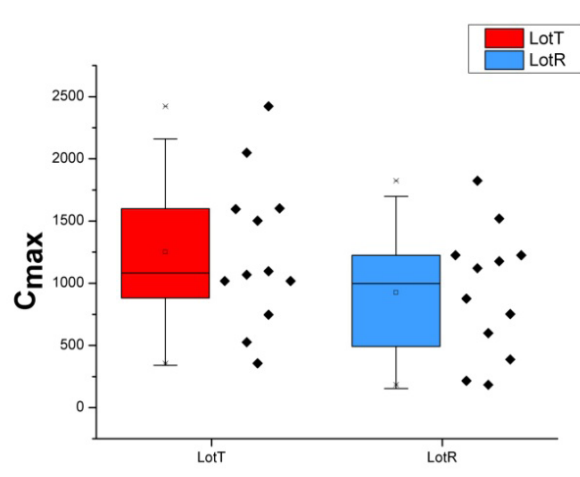

Fig.1. Individual variations of the $\mathrm{C}_{\max }$

biochemical tests. The bioequivalence testing was performed in two phases, separated by a washout period of 14 days. In each stage the cats received a drug containing either $20 \mathrm{mg}$ (TEST) or $50 \mathrm{mg}$ (REFERENCE) of praziquantel. The administration of tablets was performed according to a randomization list. After drug administration, 11 blood samples were collected from each cat, over a three days period, at predetermined times.

\section{RESULTS AND DISCUSSIONS}

The analysis of the chemical composition of the two tested formulas, displayed that, regarding the active formula praziquantel, the quantity from the two products was not even. Thus, the REFERENCE product contained $50 \mathrm{mg}$ and the TEST product contained $20 \mathrm{mg}$. The results recorded for $\mathrm{C}_{\max }$ and $\mathrm{T}_{1 / 2}$ had individual variations, consistent with the drug administered (test or reference) however without statistical significance. Regarding the results obtained for the maximum concentration $\left(\mathrm{C}_{\max }\right)$, there are observed fluctuations of the individual values and also variations of the mean results obtained (Fig.1). Thus, for the TEST product, a mean value of $1250.58 \pm 607.53 \mathrm{ng} /$ $\mathrm{mL}$ was obtained, with a maximum of 2423.21 $\mathrm{ng} / \mathrm{mL}$ and a minimum of $356.96 \mathrm{ng} / \mathrm{mL}$. For the REFERENCE product, the mean recorded value was $925.78 \pm 515.39 \mathrm{ng} / \mathrm{mL}$, with a maximum value of $1823.89 \mathrm{ng} / \mathrm{mL}$ and a minimum value of $184.68 \mathrm{ng} / \mathrm{mL}$.

For the products half-life, as it can be noticed in Fig. 2, only minor fluctuations of the individual results were recorded. This aspect is

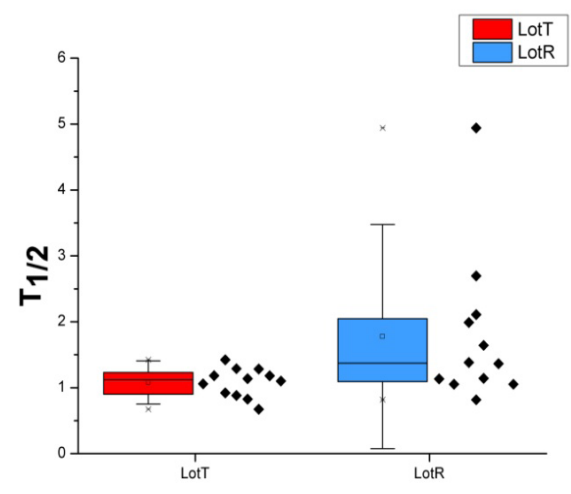

Fig.2. Individual results for $\mathrm{T}_{1 / 2}$

more noticeable for the test product, were small variations of the individual results were noted with regard to the mean value $(1.08 \pm 0.21 \mathrm{~h})$. The values recorded for the reference product varied slightly, the recorded mean being of $1.77 \pm 1.13 \mathrm{~h}$. Correlating the results with the maximum time of absorption $(1.16 \pm 0.38 \mathrm{~h}$ for the tested product, and $1.25 \pm 0.26 \mathrm{~h}$ for the reference product) it can be stated that the tested product is much more rapidly absorbed in the blood stream, in a higher concentration, being also eliminated faster.

\section{CONCLUSION}

Since the two products had a different concentration of praziquantel, the individual results obtained indicate that there are variable fluctuations between the two products. The results show that the tested product is absorbed in a higher quantity in the cats body, having a shorter half-life and thus being eliminated faster.

Acknowledgements. This paper was published under the frame of European Social Fund, HumanResources Development Operational Programme 2007-2013, project no.POSDRU/159/ 1.5/S/136893.

\section{REFERENCES}

1. Ognean L, Cernea C, Cernea M and Tripon S (2008). Evaluarea biodisponibilit?ții comparative a doua antihelmintice pe baza de fenbendazol, praziquantel şi pyrantel pamoat. Clujul Medical Veterinar 14:26-32.

2. Romeo-Teodor C, Chirciu V (2010). Elemente de farmacovigilenț? şi toxicologie în medicina veterinară. Brumar, Timisoara. 